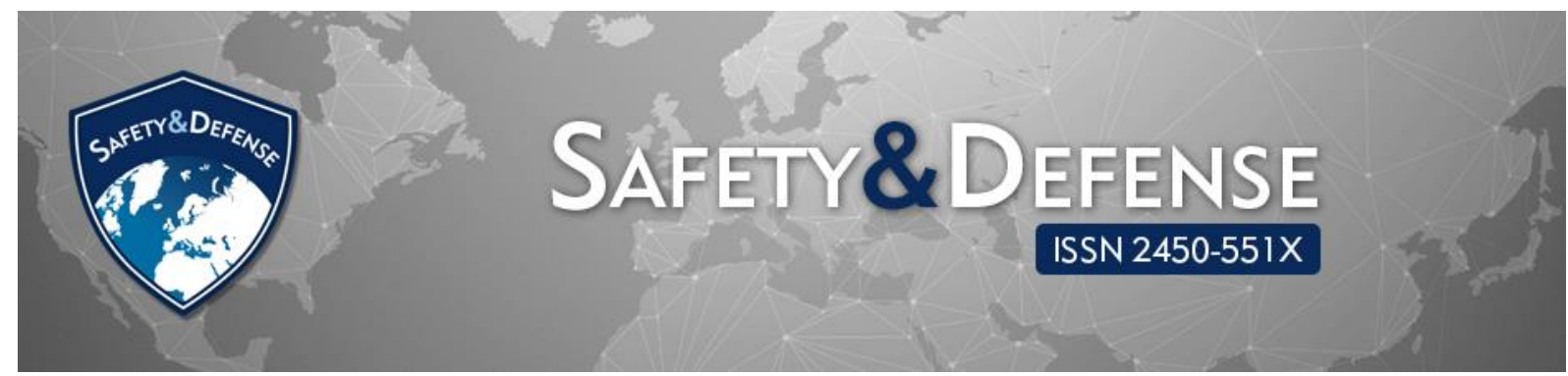

\title{
The Assignment Soldiers for Missions Abroad Regarding Sta- tus of the Polish Armed Forces
}

\author{
Adriana KRUCZYŃSKA \\ Independent researcher, Warsaw, Poland; email: adus.t@wp.pl, ORCID: oooo-ooo1-5316-3725
}

DOI: https://doi.org/10.37105/sd.78

\begin{abstract}
For many years, Polish soldiers have been conducting tasks abroad related to the state's defense policy. Despite this fact, there are few publications in scientific literature on the issue of selecting soldiers to conduct tasks abroad. For this reason, the subject of considerations was the assignment or the appointment soldiers for missions abroad with the simultaneous clarification of the legal status of the Polish Armed Forces.

This topic settled the purpose for considerations which aims to find the legal basis for: conducting tasks by the armed forces abroad, their scope and regulations regarding the assignment or appointment of soldiers to conduct tasks as a part of the armed forces. In the light of the above, the following research problem should have been solved: is there a relationship between existing regulations that reflect the relationship between the armed forces and the soldiers in its structures in the aspect of conducting tasks abroad?

Before proceeding to solve the stated issue it was hypothesized that there is a close relationship between the regulations regarding the assignment of soldiers to conduct tasks abroad. During the deliberations, theoretical research methods were implemented: a method of analysis of valid legal acts and subject literature, followed by the synthesis method to formulate conclusions and generalizations.

The considerations end with generalizations regarding the valid legal status concerning the assignment or appointment of soldiers on missions abroad and the status of the Polish Armed Forces.
\end{abstract}

Keywords: missions, armed forces, defense, designation and directing of soldiers 


\section{Introduction}

It is highlighted in the literature that the defense of the Republic of Poland is one of the fundamental area of activities of the country in the sphere of national security, and that in common understanding, it is associated with the capability to defend borders and the basic needs of the nation with the use of military force (Socha, 2020). It is undoubtedly an accurate definition, nevertheless nowadays, defense consists of many more elements, e.g. the participation of the Polish Armed Forces in many types of missions abroad. These have become the real signum temporisof the past and present and their definition is varied: from commission missions (e.g.: Neutral Nations Supervisory Commission in the North Korea and the South Korea, International Commission for Supervision and Control in Cambodia), through observation missions (e.g.: Observer Team in Nigeria, United Nations Iran-Iraq Military Observer Group in Iran), peacekeeping (e.g.: United Nations Emergency Force II in Syria, United Nations Interim Force in Lebanon), humani-

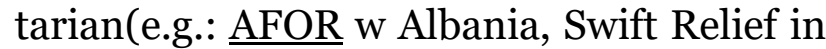
Pakistan), police(e.g.: United Nations Guards Contingent in Iraq), to training (e.g.: NATO Training Mission - in Afghanistan, European Union Training Mission in Mali), and war (e.g.: International Security Assistance Force in Afghanistan) ones. It is pointed out in the literature that fighting against international terrorismalso requires allied military operations to minimalize threats to national security (Żurawski et al., 2019, p. 22).

It proves that Poland embeds itself in the multinational environment as a political body focused on materializing the idea of the necessity for cooperative problem solving, including conflicts, and on introducing global order.

In the Military Encyclopaedia, a military mission means participation of a military unit assigned at the invitation of an another country or ordered by international organizations (e.g. the UN Security Council) to monitor truce agreements (Military Encyclopedia, 2007, p. 626). Similarly, the notion of a mission was defined by E. J. Osmańczyk. In his opinion, a military mission is military representation assigned at the invitation of an another country to achieve strict goals: advisory, assistant or on order of international controlling or mediatory organizations (Osmańczyk, 1987, p. 323).

The formal basis for the participation of the Polish Armed Forces in missions abroad are national and international legal regulations. This means that every participation of the Polish Armed Forces in missions abroad has to be based on current legal regulations, as article 2 of the Constitution states that the Republic of Poland is a democratic legal state (Constitution of the Republic of Poland).

Preliminary approval of the importance of the Polish Armed Forces' participation in missions abroad allowed for the thesis that there is a connection between the armed forces' area of responsibility and the duties of soldiers assigned or appointed for service abroad. The first argument for this thesis is the fact that the success of country's missions abroad depends on the appropriate choice of soldiers. The second argument is the fact that the guarantee of quality for tasks fulfilled by the armed forces on the mission abroad depends also on the appropriate choice of soldiers(Chodubski, 2008, p. 308).

\section{The norms regarding the participa- tion of armed forces in military con- tingents}

Considering the topic of the foundation for norms regarding the participation of the armed forces in missions abroad, it should be evaluated by defining its legal basis. In the subject matter, Article 26 item 1 of the Constitution of the Republic of Poland, which states that the armed forces serves to protect the independence of a country or 
the indivisibility of its territory as well as to ensure the security and inviolability of its borders is of great importance. This rule expresses the idea of homeland defense not only within the borders and in geographically close territories, but also in other regions if there is a threat to security and peace, which could cause concern for Poland as well (The statement of constitutional Court).

Article 3 item 1 of the Act of 21 November 1967 on the Common defense Duty of the Republic of Poland (Act of 21 November) also is decisive with regards to distinctive role of the armed forces serving abroad. According to the abovementioned act, the Polish Armed Forces defend the sovereignty and independence as well as security and peace of the Polish nation.

No less important and basic for the participation of armed forces abroad is Article 3 Section 2b, of the abovementioned act, which authorizes the armed forces to engage coercive means, firearms and other armaments abroad within the frames of legal rules obligatory for the Republic of Poland on the basis of international agreements and international common law as well as laws regarding the aim of the engagement of force abroad.

The next fundamental legal act that regulates the deployment of the armed forces abroad is the Act of 17 December 1998 on the Rules of Engagement or Stay of the Polish Armed Forces Abroad(Act of 17 December 1998), which describes matters with regards to the engagement or stay of operational and tactical forces as well as units and subunits abroad.

Next to the national regulations concerning the participation of armed forces, international bilateral or multilateral agreements should also be mentioned.

The specific legal act for the participation of armed forces in military contingents is the Article 5 of the North Atlantic Treaty issued in Washington on 4 April 1949 (The North Atlantic Treaty). Within its frames, the participants agreed that aggression towards one or more signatories in Europe or in the North America will be treated as aggression towards everyone. That is why they agree if such aggression would appear, then every signatory within the rule of individual or collective self-defense acknowledged on the basis of Article 51 of the United Nations Charter will support the assaulted party or parties by taking short notice actions alone as well as together with other participants, actions as it recognizes as necessary including the use of the armed forces in order to regain and sustain the security of the North Atlantic area.

The second special source of law for the armed forces participation in missions abroad is the international agreement is Article 51 of the United Nations Charter (The United Nations Charter). According to mentioned article, if UN Security Council states that assets foreseen in Article 41 will be insufficient, or already have been so, it may conduct by air, maritime or land forces such as action that it states to be necessary to sustain or regain international peace and security. This action may regard the demonstration, blocking or other air, maritime or land forces operations of United Nations members.

Apart from abovementioned international multilateral agreements, the basis for the participation in missions abroad can be also international bilateral agreements.

The presented regulations lead to the following conclusions: The armed forces face a highly important scope of tasks. Apart from conducting defense tasks on the territory of one's own country, the armed forces may be used to conduct missions abroad.

\section{Regulations concerning the scope of tasks for the Military Contingent}

Considering the status of the armed forces in the aspect of conducting tasks abroad, one cannot be ignore Article 2 of the Constitution, which states that the Re- 
public of Poland is a democratic state of law. The presented content of the constitutional provision influences the role of military authorities responsible for conducting tasks abroad by military units.

In this context, the term "military authorities" should be understood as a deliberately organized and clearly separated team of people and assets, created and operating on the basis of law, conducting specific tasks on behalf of the state entitled to use the means of authority and state coercion for their implementation (Przyjemski, 2009).

The presented view is reflected in the legal regulations concerning the armed forces envisaged to participate in abroad.

With regards to Article 2 of Act of 17 December 1998 on the Rules of Engagement or Stay of the Polish armed Forces, the armed forces may be "engaged" or "stay" outside the country. In the light of the abovementioned act, ,"the engagement of armed forces" means the presence of military units abroad for the purpose of:

a) armed conflict or for strengthening the forces of the state or allied states;

b) peace-keeping missions;

c) the prevention of acts of terrorism or their effects.

However, "the deployment of the Polish Armed Forces abroad" is identified with the presence of military units abroad in order to participate in:

a) military training and exercises;

b) search \& rescue and humanitarian activities;

c) representative projects.

The nature of the division between "the engagement" and "the deployment" of the Polish Armed Forces in the missions abroad is decided by the type of conducted tasks. In the first case, engagement is associated with conducting military tasks. In the second case, with conducting tasks that can be described as ,"peaceful actions", thus excluding the participation of armed forces in military actions.
The presented nature of the tasks conducted by the armed forces within the missions abroad lies within the competence of various institutions. The opinion expressed in the literature is that in a democratic state, the existence of a state body is based on law, which at the same time defines the competence of this body and limits its activity (Skrzydło, 2002). Sharing the doctrine, it should explained that the President of the Republic of Poland decides to engage military units abroad, at the request of two authorities: the Council of Ministers and the Prime Minister. At the request of the Council of Ministers, in the case of the engagement of the Polish Armed Forces abroad in order to participate in an armed conflict or to strengthen the national forces or allied parties, or a peace-keeping mission. At the request of the Prime Minister regarding participation in the prevention of acts of terrorism or their effects. The President of the Republic of Poland immediately informs the Marshals of the Sejm and the Senate about his decision.

In turn, the Council of Ministers has the competence to deploying military units abroad remains for military training and exercises, if funds for these have not been included into the budgets of relevant ministries.

Competences regarding the deployment of military units abroad are also held by the Minister of National Defense or the Minister of the Interior in relation to subordinate units in the case of:

a) military training and exercises;

b) search \& rescue and humanitarian activities;

c) representative projects.

In each of the indicated cases, a decision to deploy military units abroad is taken by the Prime Minister and notified to the President of the Republic of Poland. 


\section{Regulations concerning soldiers conducting tasks as the part of the armed forces.}

The third category of legal acts includes regulations regarding the status of soldiers as the part of the armed forces conducting missions abroad. These regulations are based on the Act of 11 September 2003 on the Military Service of Professional Soldiers (Act of 11 September 2003) as well as on executive regulations in the Regulation of the Council of Ministers of 10 March 2015 on the military service abroad (Regulation of the Council of Ministers of 10 March 2015). Undoubtedly, the status of a professional soldier on duty in a mission abroad is based on the Act on the Military Service of Professional Soldiers. Evidence of this is found in Article 3 item 2, which states that professional soldiers perform the professional military service for the benefit of the Republic of Poland. This service requires discipline, loyalty and dedication. The presented statement remains in line with Article 24 item 1 of the above-mentioned act, which states that a professional soldier may be assigned or appointed to conduct the professional military service abroad. The presented regulation indicates that the legislator introduced two bases for the service conducted by soldiers in mission abroad, i.e. 'assignment' and 'appointment'.

According to the applicable regulation, the Minister of National Defense, as the highest superior in the armed forces appointing professional soldiers to positions from the rank of colonel (commander) to the rank of general (admiral). As emphasized in the literature, the Minister of National Defense, as the only constitutional minister directing the departments of governmental administration, possesses an individually defined legal status for his office(Padzik, 2018, p. 123). In this respect, the role of the Minister results from the Article 1 item 1 of the Act of 14 December 1995 on the Office of the Minister of National Defense(Act of 14 December 1995) accord- ing to which the Minister of National Defense supervises the governmental administrative branch. Moreover, Article 2 item 12, which states that the scope of activity of the Minister of National Defense includes implementing decisions of the Council of Ministers with regards to the participation of the Republic of Poland in the military activities of international organizations in the field of fulfilling military obligations arising from international agreements. However, the competencies to appoint to positions of other professional soldiers are directed to the director of the department for human resources in the Ministry of National Defense.

In turn, competences to assign soldiers to conduct the professional military service abroad are directed to the Chief of the General Staff of the Polish Army.

Another issue addressed in legal regulations is the subordination of soldiers assigned to service abroad. The legal basis for this is found in Article 24 item 4 of the Act on the Military Service of Professional Soldiers.

According to the aforementioned act, while conducting professional military service abroad, a professional soldier is subjected to the authority that assigned or appointed him to this service, or to the authority indicated by the Minister of National Defense. It should be added that while conducting duties abroad, a professional soldier may be subject, depending on the place of the military service, to:

1) the supervisor directing the activities of the mission of an international organization or multinational forces;

2) the head of a foreign post in which a soldier was appointed to conduct the professional military service;

3) a Polish military representative - in the case of conducting service in a Polish military representation at an international organization or at an international military structure or at the armed forces or defense structures of a foreign country; 
4) the superior specified by an international organization or international military structure, in the case of conducting a service directly in the structures of international organizations or international military structures, and in the case of national affairs - a senior national officer;

5) the superior specified by the competent authority of the armed forces or other defense structures of a foreign state, in which forces or structures a soldier conducts the military service.

It should be added that in accordance with Article 47 Section 1a of the discussed act, a professional soldier appointed to serve abroad may be assigned to conduct duties outside the place of a service once for a period not longer than twelve months. At the same time, soldier remains at the post in the current military unit.

As already indicated above, specific issues regarding the assignment and appointment of soldiers to conduct professional military service abroad are regulated by an executive act to the Act of 11 September 2003 on the Military Service of Professional Soldiers, i.e. by the Regulation of the Council of Ministers of 10 March 2015 on the conduct the professional military service abroad, which specifies the legal regulations regarding soldiers assigned or appointed to conduct military service abroad. According to the aforementioned regulation, the assignment a soldier to conduct professional military service abroad of occurs in cases of service on the following posts:

1) in Polish military representations in:

a) international organizations,

b) international military structures;

2) directly within the structures of international organizations and international military structures;

3 ) in defense attaches at diplomatic representations and permanent representations at international organizations subordinate to the Minister of Foreign Affairs, having its headquarters abroad;
4) at the armed forces or other defense structures of foreign states.

Duty posts in Polish military representations at international organizations and international military structures are included in the positions "List of duty posts intended for professional soldiers serving abroad", organized separately for the posts presented above.

According to the aforementioned regulation, an appointment of a soldier to conduct the professional military service abroad occurs when:

1) in the case of conducting a service:

a) in the structure of a military unit engaged outside the country,

b) in the main headquarters, headquarters and staffs of international organizations missions and multinational forces,

c) as a military observer or a person with the status of a military observer in the peace-keeping missions of international organizations and multinational forces.

A soldier is appointed to perform professional military service abroad also in order to:

a) secure the functioning of a military unit engaged abroad in the area of its operation,

b) ensure the organization, functioning and execution of the control activity of the military unit in the area of operation.

While conducting the professional military service abroad, a soldier remains in the last occupied post or in the personnel reserve.

Assigning a soldier to conduct professional military service abroad is made by a decision. However, the appointment of a soldier to conduct professional military service abroad is made by an individual or collective order(Karakiewicz, et al., 2018).

The condition for assigning or appointing a soldier to conduct professional military service abroad is to obtain a medical certificate stating the absence of health con- 
traindications to conduct this service. Nevertheless, the assignment a soldier to serve in permanent representations at international organizations having their headquarters abroad takes place after consultation with the Minister of Foreign Affairs.

In case that conducting professional military service abroad will be associated with access to information designated to be classified by the state in which a soldier is to conduct service, or by the international organization at which the Polish representation operates, or in the structure in which a soldier is to conduct service, and an agreement on mutual protection of classified information is concluded with this country or organization, a candidate should have a security clearance corresponding with regulations on the protection of classified information(Tannheimer, and Neitzel, 2014) .

An extremely important issue is the possibility of repealing the decision to assign a soldier to conduct professional military service abroad and to call back to the country. The competence to repeal the decision to assign a soldier to conduct professional military service abroad is directed to the Minister of National Defense and the director of the department of the Ministry of National Defense for Human Resources and the Chief of the General Staff of the Polish Army - in the scope of repealing the order to appoint a soldier to conduct this service.

These competences are effective in relation to assignment and appointment- issued before the day of departure from the country. Furthermore, in case of a refusal to accept a soldier by the state or an international organization, and in case of health contraindications of the soldier to conduct the professional military service abroad, or withdrawal of the security clearance.

The reason for revoking the decision to appoint a soldier or an order to conduct professional military service, the day before a departure from the country may be:

a) a legally binding punishment of a soldier for a disciplinary offense, b) the initiation of a criminal proceeding against a soldier for a crime,

c) an offense proceeding,

d) a suspension of a soldier in duties,

e) the request of a soldier;

f) the justified need of the Polish Armed Forces.

Considering calling a soldier from the military contingent back to the country may be conducted on the basis of:

a) a proposal a public authority of a country: in which armed forces or structures a soldier serves: in which an international organization prospers: in which Polish military representation functions;

b) a proposal of an international organization or a military structure, in which representation functions;

c) a proposal of public authority, in which territory they have its location and a proposal of the commander of international forces;

d) a proposal of the Ministry of Foreign Affairs regarding a soldier assigned for tasks in the permanent representation at international organizations;

e) defined health contraindications to conduct abroad service;

f) the loss of access to classified information demanded on the particular post.

It has to be noticed that in the current legal status, there is a possibility to call a soldier back to the country any time in one of the following cases:

1) failure to perform duties or their improper realization;

2) the final punishment of a soldier in a disciplinary proceeding, the initiation of a criminal proceeding for a crime against a soldier, a proceeding in a case for an offense, the suspension of a soldier in official duties and in the event of a probable suspicion of committing an act which is prohibited under penalty of the residence country's law, or an initiation of a disciplinary proceeding against a soldier assigned to conduct a service abroad;

3) the written request of a soldier or a commander of a military unit, in which 
the soldier serves abroad or the following superiors:

a) the head of a mission of an international organization or multinational forces;

b) established by an international organization or an international military structure;

c) determined by the proper authority of the armed forces or defense structures of a foreign country;

d) the head of a foreign post in which a soldier was appointed to conduct professional military service;

e) a Polish military representative - in the case of conductingservice in a Polish military representation at an international organization or at an international military structure;

4) the justified needs of the Polish Armed Forces;

5) failure to conduct duties.

With regards to presented norms, it has to be stated that valid norms concerning the possibility of repealing decisions on the assignment soldier to a service in military contingents and calling him/her back to the country create opportunities for the optimal guarantee for conducting tasks,and at the same time, achieving goals of the armed forces designated for a service in military contingents.

\section{Conclusions}

The arrangements in the topic of the assignment or the appointment of soldiers for missions abroad considering the status of the Polish Armed Forces lead to the following conclusions.

There is coherence and complementarity of the legal provisions regarding the engagement of the Polish Armed Forces abroad, as well as conducting military service by soldiers in military units assigned for this purpose from the armed forces. The participation of the armed forces and soldiers in actions abroad remains in line with Poland's policy of ensuring external securi- ty, which is expressed in alliances and international obligations.

It is also worth noticing how detailed the normative regulation concerning the selection of soldiers to conduct missions abroad proceeded by military authorities in the form of an assignment or an appointment.

In this situation, it should be considered that the research problem stated in the methodological foundations of this article has been solved. This means that there are neither normative contradictions for the Armed Forces to operate abroad nor restrictions to normative regulations regarding the appointment or assignment of soldiers for missions abroad.

At the same time, it has to be highlighted that legal regulations describe the participation of soldiers and military units, assigned from the Polish Armed Forces to different types of missions conducted under international institutions, on the territory of other countries.

\section{References:}

1. Act of 11 September 2003 on the Military Service of Professional Soldiers (Journal of Laws 2019 items 330, 730, 1726).

2. Act of 14 December 1995 r. On the office of the Minister of National Defense (Journal of Laws 2019, item 196).

3. Act of 17 December 1998 on the Rules of Engagement or Stay of the Polish Armed Forces Abroad (Journal of Laws 1998 no. 162 item 1117 with further changes

4. Act of 2 April 1997 - The Constitution of the Republic of Poland (Journal of Laws 1997, no. 78, item 483 with further changes).

5. Act of 21 November 1967on the Common Defense Duty of the Republic of Poland (Journal of Laws 2015, item 827 with further changes). 
6. Chodubski, A. (2008). Polityczne znaczenie udziału Wojska Polskiego w misjach zagranicznych ONZ i NATO. Studia Gdańskie, V, pp. 300309.

7. Karakiewicz, B., and Rozmarynowska, B., and Paszkiewicz, M., and Zabielska, P. (2018). Psychosocial aspects of participation of the Polish Armed Forces in combat missions, Psychiatria Polska. 52(5), pp. 873886

DOI:https://doi.org/10.12740/PP/O nlineFirst/75666

8. Konstytucja Rzeczypospolitej Polskiej z dnia 2 kwietnia 1997 r. (Dz. U. z 1997, Nr 78, poz. 483).

9. Military Encyclopedia, A-M (2007). Warsaw: Polish Scientific Publishing House.

10. Osmańczyk, E. J. (1987). UN and international relations Encyclopedia, Warsaw.

11. Padzik, J. (2018). Rola i znaczenie normy art. 5 Konstytucji Rzeczypospolitej Polskiej dla obszaru prawa kształtującego system obronny państwa, Studia Bezpieczeństwa Narodowego, Military University of Technology, Cybernetics Department. Organization and management Institute. Warsaw. VIII(14).

12. Przyjemski, S. M. (2009). Spory kompetencyjne między organami sprawującymi wymiar sprawiedliwości w Polsce. Ed. 1. Warsaw: Lexis Nexis.

https://sip.lex.pl/komentarze-ipublikacje/monografie/sporykompetencyjne-miedzy-organamisprawujacymi-wymiar-369216170 (available: 21.03.2020).

13. Regulation of the Council of Ministers of 10 March 2015 on conducting the military service abroad (Journal of Laws 3 April 2015, item 479).

14. Skrzydło, W. (2002). Konstytucja Rzeczypospolitej Polskiej. Kraków: Zakamycze.
15. Socha, R. (2020). Przygotowania obronne Policji w latach 1919-2019 w 100-lecie powstania formacji. Wiedza Obronna, 270(1). DOI:https://doi.org/10.34752/602xpn62

16. Tannheimer, M., and Neitzel, C. (2014). Missions of the German bundeswehr and travel medicine aspects. Arbeitsmedizin Sozialmedizin Umweltmedizin. https://www.asuar-

beitsmedizin.com/wissenschaft/ausl andseinsaetze-der-bundeswehr-ausreisemedizinischer-sicht (available: 21.03.2020)

17. The North Atlantic Treaty issued in Washington of 4 April 1949 (Journal of Laws 2000, no. 87, item 970).

18. The statement of constitutional Court of 9 June 1997 (Doc. K. 24/96).

https://www.saos.org.pl/judgments/ 205756 (available: 21.03.2020).

19. The United Nations Charter, Governmental statement of 8 July 1946 on ratification The United Nations Charter signed by Poland in Washington on 16 October 1945 (Journal of Laws 1947 no. 23, item 91).

20. Żurawski, S., and Cekanowski, Z., and Zakrzewski, R. (2019). Udział polski w zwalczaniu terroryzmu. Edukacja dla Bezpieczeństwa, 3 (44), pp. 15-30. http://www.przeglad.wsb.net.pl/upl oads/1/o/3/7/10371016/pnm_2_20 19_wersja2.pdf (available: 21.03.2020). 